\title{
Improvement of Thematic Learning Outcomes through Problem Based Learning Model in Class III Theme 3 Students SDN 1 Kebondalem
}

\author{
Ali Muntoif \\ SD Negeri 1 Kebondalem \\ toifalimuntoif@gmail.com
}

\section{Article History}

accepted $14 / 11 / 2020$

approved $21 / 11 / 2020$

published 26/11/2020

\begin{abstract}
The purpose of this study was to improve the quality of Thematic learning for grade III students by using the Project Based Learning (PjBL) model assisted by Media Power Point. The research conducted was a Classroom Action Research (CAR) in two cycles, with each cycle consisting of one meeting. The stages of each cycle are planning, implementing, observing and reflexing. Each meeting is carried out a pre test and post test to determine the progress of students. In the first cycle, the students who completed after carrying out the post test were $60 \%$. In cycle II students who completed after carrying out the post test were $90 \%$. These results indicate that the Project Based Learning (PjBL) learning model can improve student learning outcomes, especially Thematic muples. Themes: 3 Objects Around Me Class III at SDN I Kebondalem
\end{abstract}

Keywords: Learning outcomes, problem based learning

\section{Abstrak}

Tujuan dari penelitian ini meningkatkan kualitas pembelajaran Tematik siswa kelas III dengan menggunakan model Project Based Learning (PjBL) berbantuanMedia Power Point.Penelitian yang dilakukan adalah Penelitian Tindakan Kelas ( PTK) sebanyak dua siklus, Dengan setiap siklusnya teridiri dari satu pertemuan. Tahapan setiap siklusnya adalah perencanaan, pelaksanaan, observasi dan reflex. Setiap pertemuan dilakukan pre test dan post test untuk mengetahui perkembangan peserta didik. Pada siklus I peserta didik yang tuntas setelah melaksanakan post test sebesar $60 \%$. Pada siklus II peserta didik yang tuntas setelah melaksanakan post test sebesar $90 \%$. Hasil ini menunjukan bahwa model pembelajaran Project Based Learning (PjBL) dapat meningkatkan hasil belajar peserta didik khususnya mupel Tematik Tema :3 Benda di Sekitarku Kelas III di SDN I Kebondalem

Kata kunci: hasil belajar, problem based learning

Social, Humanities, and Education Studies (SHEs): Conference Series https://jurnal.uns.ac.id/shes

p-ISSN 2620-9284

e-ISSN 2620-9292 


\section{PENDAHULUAN}

Pendidikan menurut Undang-Undang Nomor 20 Tahun 2003 tentan Sistem Pendidikan Nasional Bab I Pasal 1 adalah usaha sadar dan terencana untuk mewujudkan suasana belajar dan proses pembelajaran agar peserta didik secara aktif mengembangkan potensi dirinya untuk memiliki kekuatan spiritual keagamaan, pengenalan diri, kepribadian, kecerdasan, akhlak mulia, serta keterampilan yang diperlukan dirinya, masyarakat, bangsa dan negara.

Implementasi Undang-Undang Nomor 20 Tahun dijabarkan kedalam sejumlah peraturan, seperti dalam Peraturan Pemerintah Nomor 19 Tahun 2005 Pasal 6 Ayat 1 tentang Standar Nasional Pendidikan menyatakan bahwa kurikulum untuk jenis pendidikan umum, kejuruan, dan khususnya pada pendidikan dasar dan menengah terdiri atas kelompok mata pelajaran agama dan akhlak mulia, kelompok mata pelajaran kewarganegaraan dan kepribadian, kelompok mata pelajaran ilmu pengetahuan dan teknologi, kelompok mata pelajaran estetika, dan kelompok mata pelajaran jasmani dan kesehatan. Mengacu pada UndangUndang Nomor 20 Tahun 2003 Pasal 37 Ayat 1 Tematik adalah mata pelajaran yang wajib diberikan kepada siswa sekolah dasar. Berdasarkan Standar Kompetensi dan Kompetensi Dasar Tingkat SD/MI dalam Peraturan Menteri Pendidikan Nasional Nomor 22 Tahun2006 tentang standar isi untuk satuan pendidikan dasar dan menengah bahwa standar Tematik berhubungan dengan cara mencari tahu tentang sistematis, sehingga Tematik bukan hanya penguasaan kumpulan pengetahuan yang berupa fakta-fakta, konsep-konsep, atau prinsipprinsip saja tetapi juga merupakan suatu proses penemuan.

Tujuan pembelajaran Tematik di SD/MI adalah (1) memperoleh keyakinan terhadap Tuhan Yang Maha Esa berdasarkan keberadaan, keindahan dan keteraturan alam ciptaan-Nya; (2) mengembangkan pengetahuan, pemahaman konsep-konsep yang bermanfaat diterapkan dalam kehidupan sehari-hari; (3) mengembangkan rasa ingin tahu, sikap kognitif dan kesadaran tentang adanya hubungan saling mempengaruhi antara Tematik, lingkungan, teknologi dan masyarakat; (4) mengembangkan keterampilan proses untuk menyelidiki alam sekitar, memecahkan masalah, dan membuat keputusan; (5) meningkatkan kesadaran untuk berperan serta dalam memelihara, menjaga dan melestarikan lingkungan alam; (6) meningkatkan kesadaran untuk menghargai alam dan segala keteraturannya sebagai salah satu ciptaan Tuhan; (7) memperoleh bekal pengetahuan, konsep dan keterampilan Tematik sebagai dasar untuk melanjutkan pendidikan ke SMP / MTs. (Depdiknas, 2006).

Menurut Boss dan Kraus, Model Pembelajaran Berbasis Proyek (MPBP) adalah sebuah model pembelajaran yang menekankan aktivitas siswa dalam memecahkan berbagai permasalahan yang bersifat open-ended dan mengaplikasi pengetahuan mereka dalam mengerjakan sebuah proyek untuk menghasilkan sebuah produk otentik tertentu (Abidin, 2007:167).

Model pembelajaran Project Based Learning dikembangkan berdasarkan tingkat perkembangan berfikir siswa dengan berpusat pada aktivitas belajar siswa sehingga memungkinkan mereka untuk beraktivitas sesuai dengan keterampilan, kenyamanan, dan minat belajarnya. Model ini memberikan kesempatan pada siswa untuk menentukan sendiri proyek yang akan dikerjakannya baik dalam hal merumuskan pertanyaan yang akan dijawab, memilih topik yang akan diteliti, maupun menentukan kegiatan penelitian yang akan dilakukan. Peran guru dalam pembelajaran adalah sebagai fasilitator, menyediakan bahan dan pengalaman bekerja, mendorong siswa berdiskusi dan memecahkan masalah, dan memastikan siswa tetap bersemangat selama mereka melaksanakan proyek

Model pembelajaran Project Based Learning mempunyai beberapa karakteristik, yaitu sebagai berikut (Winastaman Gora dan Sunarto, 2010:119): 
1. Mengembangkan pertanyaan atau masalah, yang berarti pembelajaran harus mengembangkan pengetahuan yang dimiliki oleh siswa.

2. Memiliki hubungan dengan dunia nyata, berarti bahwa pembelajaran yang outentik dan siswa dihadapkan dengan masalah yang ada pada dunia nyata.

3. Menekankan pada tanggung jawab siswa, merupakan proses siswa untuk mengakses informasi untuk menemukan solusi yang sedang dihadapi. hasil

4. Penilaian, penilaian dilakukan selama proses pembelajaran berlangsung dan

\section{METODE}

Penelitian ini adalah penelitian tindakan kelas (Classroom Action Research) dengan menerapkan model pembelajaran Project Based Learning (PjBL). Menurut Kurt Lewin dalam Kunandar (2011: 42) penelitian tindakan kelas ini terdiri dari empat tahapan dasar yaitu perencanaan (planning), pelaksanaan (acting), pengamatan (observing) dan refleksi (reflecting). Analisis penelitian ini adalah analisis deskriptif kuantitafif kualitatif dimana dalam penelitian ini selain penyajian hasil berupa data maupun angka peneliti juga menentukan bagaimana cara pengolahan hasil penelitian yakni dengan membuat analisisnya dengan menerapkan model penelitian Project Based Learning (PjBL). Penelitian ini dilaksanakan pada peserta didik kelas III SD Negeri 1 Kebondalem Tahun Pelajaran 2020/2021 selama dua siklus secara luring menggunakan media power point dengan dua pertemuan disetiap siklusnya. Siklus I dilaksanakan pada tanggal 16 November 2020. Siklus II dilaksanakan pada tanggal 23 November 2020. Teknik pengumpulan data yang dilakukan dengan observasi dan tes,

\section{HASIL DAN PEMBAHASAN}

Pada siklus I pembelajaran dilaksanakan satu pertemuan, yaitu pre test dan post test. Untuk mengetahui perkembangan peserta didik selama pembelajaran. Siklus I membahas materi tentang pengembunan dilingkungan sekitar. Pembelajaran dengan model PjBL dilaksanakan dengan 6 langkah PjBL secara berurutan mulai dari menentukan pertanyaan mendasar, merancang proyek, menyusun jadwal, memantau proses proyek, penilaian hasil dan evaluasi pengalaman. Proyek yang dibuat peserta didik adalah menyebutkan Contoh pengembunan dilingkungan. Berikut ini adalah hasil belajar peserta didik pada siklus I yang bisa dilihat pada tabel berikut.

Tabel 1. Hasil Belajar Peserta Didik Siklus I

\begin{tabular}{|c|c|c|c|c|c|c|c|c|}
\hline \multirow{3}{*}{ Siklus I } & \multicolumn{4}{|c|}{ Pre test } & \multicolumn{4}{|c|}{ Post test } \\
\hline & & & & $\begin{array}{l}\text { dik } \\
\text { um } \\
\text { as }\end{array}$ & & & & $\begin{array}{l}\text { dik } \\
\text { um } \\
\text { tas }\end{array}$ \\
\hline & Jml & $\%$ & $\mathrm{Jml}$ & $\%$ & $\mathrm{Jml}$ & $\%$ & $\mathrm{Jml}$ & $\%$ \\
\hline Pertemuan & 2 & 20 & 8 & 80 & 4 & 40 & 6 & 60 \\
\hline
\end{tabular}

Berdasarkan tabel di atas maka terjadi peningkatan antara pre test dan post test pada pertemuan 1. Setiap individu peserta didik sudah mengalami peningkatan hasil belajarnya. Peserta didik mengalami peningkatan hasil belajar. Ketuntasan klasikal juga mengalami peningkatan, pada pre test hanya terdapat 2 anak yang sudah tuntas, tetapi pada post test bertambah menjadi 8 anak yang sudah tuntas dengan Kriteria Ketuntasan Minimal (KKM) sebesar 70. Berdasarkan refleksi pada siklus I maka diputuskan untuk melanjutkan ke siklus II dikarenakan belum mencapai ketuntasan klasikal yang diharapkan. Siklus II membahas materi tentang Proses pengembunan. Pembelajaran dengan model PjBL dilaksanakan dengan 6 langkah PjBL secara berurutan seperti siklus I Proyek yang dibuat peserta didik adalah mengamati proses 
terjadinya hujan. Berikut ini adalah hasil belajar peserta didik pada siklus II yang bisa dilihat pada tabel berikut.

Tabel 2. Hasil Belajar Peserta Didik Siklus II

\begin{tabular}{lcccccccc}
\hline & \multicolumn{3}{c}{ Pre test } & \multicolumn{3}{c}{ Post test } \\
\cline { 2 - 8 } Siklus II & \multicolumn{2}{c}{$\begin{array}{c}\text { Pesdik } \\
\text { tuntas }\end{array}$} & $\begin{array}{l}\text { Pesdik } \\
\text { belum } \\
\text { tuntas }\end{array}$ & $\begin{array}{c}\text { Pesdik } \\
\text { tuntas }\end{array}$ & $\begin{array}{l}\text { Pesdik } \\
\text { belum } \\
\text { tuntas }\end{array}$ \\
\cline { 2 - 9 } & Jml & $\%$ & Jml & $\%$ & Jml & $\%$ & Jml & $\%$ \\
\hline Pertemuan & 4 & 40 & 6 & 60 & 8 & 80 & 2 & 20 \\
\hline
\end{tabular}

Berdasarkan tabel di atas maka terjadi peningkatan antara pre test dan post test. Setiap individu peserta didik sudah mengalami peningkatan hasil belajarnya. Ketuntasan klasikal juga mengalami peningkatan, pada pre test hanya terdapat 8 anak yang sudah tuntas, tetapi pada post test bertambah menjadi 9 anak yang sudah tuntas dengan Kriteria Ketuntasan Minimal (KKM) sebesar 70. Pada pre test ada 6 anak yang baru tuntas, sudah meningkat menjadi 9 peserta didik yang tuntas setelah melaksanakan post test. Perbandingan antara hasil post test pada siklus 1 dan siklus 2 juga terdapat perbedaan. pada pre test siklus 2 hanya terdapat 6 anak yang sudah tuntas, tetapi pada post test bertambah menjadi 8 anak yang sudah tuntas dengan Kriteria Ketuntasan Minimal (KKM) sebesar 70. Demikian juga pada siklus 2 jumlah peserta didik yang sudah tuntas KKM mengalami peningkatan. Pada pre test ada 6 anak yang baru tuntas, sudah meningkat menjadi 9 peserta didik yang tuntas setelah melaksanakan post test. Perbandingan antara hasil post test pada siklus 1 dan siklus 2 juga terdapat perbedaan. Pada siklus 2 peserta didik yang sudah tuntas hanya ada 6 anak, sedangkan pada siklus 2 sudah meningkat menjadi 8 anak. Persentase ketuntasan klasikalnya meningkat. Dari dua siklus yang sudah dilaksanakan selama 2 pertemuan dapat dipastikan bahwa model pembelajaran PjBL dapat meningkatkan hasil belajar peserta didik pada mupel Bahasa indonesia Kelas 3 di SD Negeri 1 kutayasa. Hal ini sesuai dengan konsep atau teori yang diungkap oleh Nanang Hanafiah dan Cucu Suhana (2009:30) bahwa langkah penerapan Model pembelajaran ini merupakan model pembelajaran inovatif yang melibatkan kerja proyek dimana peserta didik bekerja secara mandiri dalam mengkonstruksi pembelajarannya dan mengkulminasikannya dalam produk nyata.

Memang benar adanya dengan model PjBL peserta didik akan membangun sendiri pengetahuannya dengan mengerjakan proyek yang diberikan. Peserta didik dapat memahami proses pengembunan dengan tepat. Pada siklus II peserta didik juga dapat memahami proses pengembunan. Hasil penelitian ini juga sesuai dengan penelitian sebelumnya yang dilakukan oleh Surya, dkk (2018) yang membuktikan bahwa model pembelajaran Project Based Learning (PjBL) dapat meningkatkan hasil belajar dan kreativitas peserta didik. model pembelajaran Project Based Learning (PjBL) merupakan salah satu model pembelajaran yang berpijak pada teori belajar konstruktivistik. Driscoll dalam Miyarso (2019: 120) menyatakan prinsip-prinsip pembelajaran kontruktivistik adalah melibatkan pebelajar dalam aktivitas nyata, negosiasi sosial dalam proses belajar, kolaboratif dan pengkajian multiperspektif, dukungan menentukan tujuan dan mengatur proses belajar, dan dorongan merefleksikan apa dan bagaimana sesuatu dipelajari. Menurut Surya, dkk (2018) Model pembelajaran Project Based Learning ( $\mathrm{PjBL}$ ) merupakan pembelajaran yang inovatif yang berpusat kepada siswa (Student Centered) dan menempatkan guru sebagai motivator dan fasilitator, dimana dalam hal ini siswa diberi peluang untuk bekerja secara otonom mengkonstruksi belajarnya. Model pembelajaran berbasis 
proyek (Project Based Learning) siswa merancang sebuah masalah dan mencari penyelesaiannya sendiri, sehingga mampu meningkatkan kreatifitas siswa untuk memunculkan penyelesaiannya sendiri membuat kegiatan pembelajaran lebih bermakna sehingga teringat. Menurut Nurfitriyanti (2016) project based learning adalah pembelajaran yang memerlukan jangka waktu panjang, menitikberatkan pada aktifitas peserta didik untuk dapat memahami suatu konsep atau prinsip dengan melakukan investigasi secara mendalam tentang suatu masalah dan mencari solusi yang relevan serta diimplementasikan dalam pengerjaan proyek, sehingga peserta didik mengalami proses pembelajaran yang bermakna dengan membangun pengetahuannya sendiri.Penekanan pembelajaran terletak pada aktifitas peserta didik untuk memecahkan masalah dengan menerapkan keterampilan meneliti, menganalisis, membuat, sampai dengan mempresentasikan produk pembelajaran berdasarkan pengalaman nyata. Metode pembelajaran project based learning memperkenankan peserta didik untuk dapat bekerja mandiri maupun dengan cara berkelompok dalam menghasilkan hasil proyeknya yang bersumber dari masalah kehidupan sehari-hari. Langkah dalam model pembelajaran Project Based Learning sangat memerlukan kemampuan berpikir kreatif siswa.

\section{SIMPULAN}

Penerapan model pembelajaran Project Based Learning (PjBL) dapat meningkatkan hasil belajar peserta didik Kelas III pada mupel tematik tema 3 Benda disekitarku. Peningkatan yang terjadi karena adanya kesan pembelajaran yang mendalam dari peserta didik tehadap materi yang diajarkan melalui setiap proyek yang dibuat. Peserta didik akan selalu teringat akan materi yang diajarkan dikarenakan mereka menemukan dan membangun sendiri pengetahuan mereka pada saat membuat proyek yang sudah disepakati. Berdasarkan penelitian yang telah dilaksanakan salah satu model pembelajaran yang harus dikuasai guru adalah PjBL karena model ini sangat cocok digunakan dalam keadaan pandemi seperti ini, apalagi dalam kondisi belajar dari rumah. Peserta didik akan membangun pengetahuannya sendiri dengan proyek yang sudah disepakati. Guru bisa memantau proses selama proyek dilaksanakan dengan bekerja sama dengan orang tua.

\section{DAFTAR PUSTAKA}

Erfrimal, F, dkk. (2017). Penerapan Model Project Based Learning (PjBL) untuk Meningkatkan Kecermatan dan Kreasi Seni Rupa. Hanafiah, dan Cucu

Firdaus. (2006). Reformasi Pembelajaran Menuju Kualitas Insan Bertaraf Dunia. Pekanbaru: Witra Irzani.

Majid, Abdul. (2014). Strategi Pembelajaran. Bandung: Remaja Rosdakarya.

Mamat, S.B. dkk. (2007). Pedoman Pelaksanaan Pembelajaran Tematik. Jakarta: Dirjen Kelembagaan Agama Islam.

Riadi, Muchlisin. (2017). "Model Pembelajaran Berbasis Proye(ProjectBasedLearning/PjBL)".https:/ berbasis-proyek.html, 12 Oktober 2020 pukul 20.11

Riadi, Muchlisin. (2019) . "Penelitian Tindakan Kelas (PTK)".

Rusman. (2011). Model-Model Pembelajaran Mengembangkan Profesionalisme Guru. Jakarta: Rajawali Pers.

Rusman. (2012). Model-Model Pembelajaran: Mengembangkan Profesionalisme Guru. Jakarta: Raja Grafindo Persada.

Suhana. (2009). Konsep Strategi Pembelajaran. Bandung: PT Refika Aditama

Suryosubroto. (2009). Proses Belajar Mengajar di Sekolah. Jakarta: Rhineka Cipta. 